\title{
Article \\ A Dual Source Switched-Capacitor Multilevel Inverter with Reduced Device Count
}

\author{
Mohammad Fahad ${ }^{1}$, Mohd Tariq ${ }^{1, *(\mathbb{D})}$, Mohammad Faizan ${ }^{1}$, Atib Ali ${ }^{1} \mathbb{1}$, Adil Sarwar ${ }^{1, * \mathbb{C}}$, \\ Hossein Dehghani Tafti ${ }^{2}$ (D), Shafiq Ahmad ${ }^{3}$ (D) and Adamali Shah Noor Mohamed ${ }^{4}$ (iD) \\ 1 Department of Electrical Engineering, ZHCET, Aligarh Muslim University, Aligarh 202002, India; \\ mfahad3@myamu.ac.in (M.F.); mohammadfaizmaihaur@gmail.com (M.F.); atibali999@gmail.com (A.A.) \\ 2 Department of Electrical, Electronic and Computer Engineering, University of Western Australia, \\ Crawley, WA 6009, Australia; hossein002@e.ntu.edu.sg \\ 3 Industrial Engineering Department, College of Engineering, King Saud University, P.O. Box 800, \\ Riyadh 11421, Saudi Arabia; ashafiq@ksu.edu.sa \\ 4 Electrical Engineering Department, College of Engineering, King Saud University, P.O. Box 800, \\ Riyadh 11421, Saudi Arabia; anoormuhamed@ksu.edu.sa \\ * Correspondence: tariq.ee@zhcet.ac.in (M.T.); adil.sarwar@zhcet.ac.in (A.S.)
}

check for

updates

Citation: Fahad, M.; Tariq, M.;

Faizan, M.; Ali, A.; Sarwar, A.;

Dehghani Tafti, H.; Ahmad, S.; Shah

Noor Mohamed, A. A Dual Source

Switched-Capacitor Multilevel

Inverter with Reduced Device Count.

Electronics 2022, 11, 67.

https://doi.org/10.3390/

electronics 11010067

Academic Editor: Jung-Min Kwon

Received: 15 November 2021

Accepted: 24 December 2021

Published: 26 December 2021

Publisher's Note: MDPI stays neutral with regard to jurisdictional claims in published maps and institutional affiliations.

Copyright: (c) 2021 by the authors Licensee MDPI, Basel, Switzerland. This article is an open access article distributed under the terms and conditions of the Creative Commons Attribution (CC BY) license (https:// creativecommons.org/licenses/by/ $4.0 /)$.

\begin{abstract}
Implementing voltage boost multilevel inverter topologies for PV and fuel cell energy sources is highly advantageous. Switched-capacitor multilevel inverters (SCMLI) have a step-up feature with low device requirements and can remove the need for high gain dc-dc converters leading to reduced overall system bulk. This work proposes a dual input SCMLI to achieve an output of nineteen levels while using a low number of components and high boosting factor and self-balancing of capacitor voltages. A comprehensive analysis of the proposed structure is presented, focusing on component requirements, cost and dynamic performance. The efficiency and loss distribution during operation is also provided. The operation and real-time performance of the SCMLI have been verified by simulation. Experimental results further validate the simulation results.
\end{abstract}

Keywords: multilevel inverter; solar PV; switched-capacitor; experimental validation

\section{Introduction}

As the installation of renewable energy systems is gaining traction across the globe, the significance of multilevel inverters (MLIs) as dc-ac conversion devices is at its zenith [1,2]. Since many renewable power sources are composed of numerous low-voltage dc sources such as solar photovoltaic cells, ultra-capacitors, or battery storage systems, they are ideal for forming multiple connected dc-links. A similar case can be observed in hydrogen-based fuel cells investigated for use in high specific energy applications like onboard power systems [3]. MLIs can generate high efficiency and power quality dc-ac conversion at high voltage and high power levels. The reduced harmonic content, reduced individual device ratings and the filter size are some of the attributes of MLIs. Traditionally, MLIs were devised as cascaded H-bridge, flying capacitor and neutral point clamped configurations. Flying capacitor and neutral point clamped topologies have substantial capacitor counts with higher levels, leading to cost and reliability issues and capacitor voltage balancing requirements [4]. Since their inception, numerous evolved configurations have been developed to eliminate their setbacks. Furthermore, the later developed topologies outperform the three traditional topologies in component counts. Currently, researchers are developing MLIs with an application-based approach with fault-tolerance, modularity, efficiency and even weight and volume requirements in mind [5-7].

Extensive efforts have been made in the design of reduced device count structures [8-10]. On a similar note, fault-tolerant reduced device count topologies $[10,11]$ and device count optimization [12] have also been investigated by researchers. Nevertheless, the need for a high number of dc sources leads to practical realization and control complexity issues, 
especially with renewable power sources with fluctuating voltage magnitudes. Initially, the inclusion of capacitors in MLIs can be observed in the two classical configurations, NPC and FC themselves. Recently, SCMLI-based topologies, including combinations of capacitors and switch modules in series / parallel configuration, have gained researchers' attention, particularly for applications where a voltage boosting feature is advantageous [13-17]. Low magnitude voltage, including PV or fuel cell, can be significantly increased as a result of this boosting feature. This warrants the exclusion of boost dc/dc converters, which would otherwise be required as intermediate devices [18], thus significantly reducing the overall generation system size, efficiency, and complexity. Nevertheless, the challenges of the inflated device count with higher levels are currently being addressed.

Interestingly, the replacement of multiple dc sources of a $\mathrm{CHB}$ with capacitors is investigated in [19], thus requiring a single dc source. The structure proposed in [20] can generate a total of nine levels using two capacitors, one dc source and nine switches with a two-fold boosting factor. The self-balancing of capacitor voltages has the benefit of eliminating the need for additional instrumentation or control circuitry. Similarly, a topology using three interconnected H-bridge structures, one dc source and two capacitors can produce seven levels with a boosting factor of three [21]. The fault-tolerant operation of an SCMLI topology is also investigated in [22]. Feedback linearization control for voltage and current ripple reduction under dynamic and steady operating conditions includes ANN (artificial neural network) in [23].

Furthermore, to reduce the switch current ratings and enable a larger power capability, the usage of multiple dc sources that can split the overall load current among multiple conduction paths is suitable. A 55-level topology with three asymmetrical dc sources and seven capacitors is proposed in [24], but the large number of components involved can negatively affect its reliability. Seven-level modified PUC active rectifier based on floating weighting factors and ANN-MPC based on Lyapunov stability were presented in [24]. A topology using two asymmetrical dc sources, four capacitors and ten switches is presented in [16] with a specific method for capacitor charge balancing. More examples of multiple dc source topologies with reduced device count and self-balancing capabilities can be observed as in [25-41].

A new SCMLI topology has been proposed. The SCMLI is able to produce higher levels with a low device count. In Section 2, the SCMLI operation has been discussed. Comparative assessment of the topology is carried out in Section 3. The performance of the topology is verified in Section 4. The structure's power loss analysis is carried out in Section 5. The conclusion of this work is presented in Section 6.

\section{Proposed Topology}

The schematic of the proposed topology is shown in Figure 1. The structure consists of two dc voltage sources, one power diode and ten switches, with two switches being bidirectional modules. The two dc sources possess per-unit values of $0.5 \mathrm{~V}_{\mathrm{dc}}$ and $2 \mathrm{~V}_{\mathrm{dc}}(\mathrm{a}$ ratio of 4:1). The two capacitors, $C_{1}$ and $C_{2}$, create the boosting effect in their operation. They are charged in series with the $2 \mathrm{~V}_{\mathrm{dc}}$ source. The proposed topology can generate a total of 19 levels. The switching states are shown in Table 1 . The ratio of the capacitors is $\mathrm{C}_{1} / \mathrm{C}_{2}=0.5$. The ratio between the total source voltage and peak output level, known as the boosting factor, is $4.5 / 2.5=1.8$. The capacitor voltages are self-balanced through charging loops on certain levels. Figure 2 illustrates the various conduction paths in operation. The peak blocking voltages across various switches are as follows.

$$
\begin{gathered}
\mathrm{V}_{\mathrm{ST} 1}=\mathrm{V}_{\mathrm{ST}^{\prime}}=0.5 \mathrm{~V}_{\mathrm{dc}} \\
\mathrm{V}_{\mathrm{ST} 2}=\mathrm{V}_{\mathrm{ST}^{\prime}}=4.5 \mathrm{~V}_{\mathrm{dc}} \\
\mathrm{V}_{\mathrm{Su}}=\mathrm{V}_{\mathrm{Su}^{\prime}}=2 \mathrm{~V}_{\mathrm{dc}} \\
\mathrm{V}_{\mathrm{Sb} 1}=\mathrm{V}_{\mathrm{dc}}
\end{gathered}
$$




$$
\begin{gathered}
\mathrm{V}_{\mathrm{Sb} 2}=3 \mathrm{~V}_{\mathrm{dc}} \\
\mathrm{V}_{\mathrm{ST} 3}=\mathrm{V}_{\mathrm{ST}^{\prime}}=4 \mathrm{~V}_{\mathrm{dc}}
\end{gathered}
$$

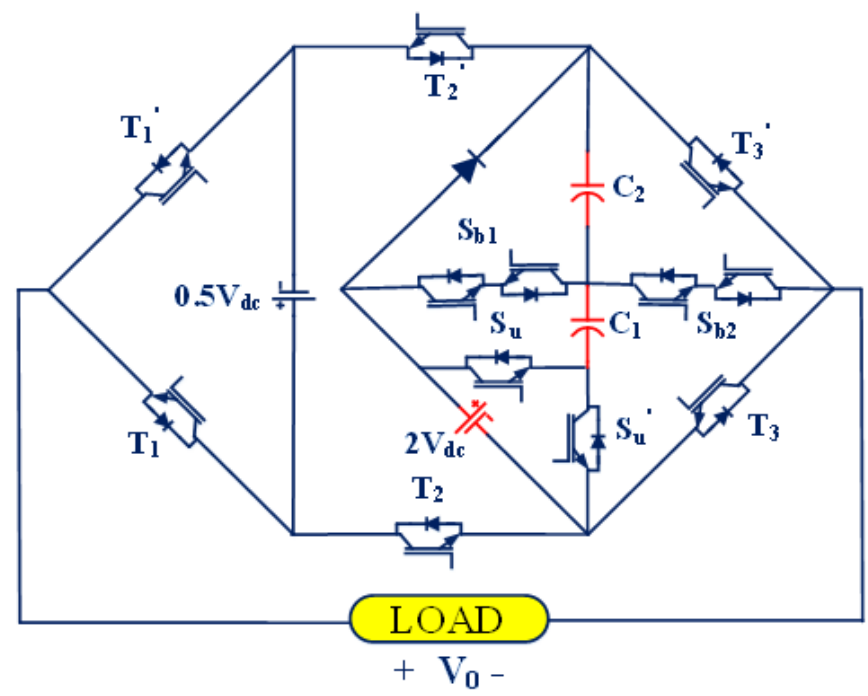

Figure 1. Structure of proposed multilevel inverter topology.

Table 1. Switching states.

\begin{tabular}{ccccccccccccc}
\hline $\mathbf{T}_{\mathbf{1}}$ & $\mathbf{T}_{\mathbf{1}}{ }^{\prime}$ & $\mathbf{T}_{\mathbf{2}}$ & $\mathbf{T}_{\mathbf{2}}{ }^{\prime}$ & $\mathbf{S}_{\mathbf{u}}$ & $\mathbf{S}_{\mathbf{b} \mathbf{1}}$ & $\mathbf{S}_{\mathbf{u}}{ }^{\prime}$ & $\mathbf{S}_{\mathbf{b} \mathbf{2}}$ & $\mathbf{T}_{\mathbf{3}}$ & $\mathbf{T}_{\mathbf{3}}{ }^{\prime}$ & $\mathbf{V}_{\mathbf{o}}$ & $\mathbf{C}_{\mathbf{1}}$ & $\mathbf{C}_{\mathbf{2}}$ \\
\hline 0 & 1 & 0 & 1 & 0 & 0 & 1 & 0 & 0 & 1 & zero & $\mathrm{C}$ & $\mathrm{C}$ \\
1 & 0 & 0 & 1 & 0 & 0 & 1 & 0 & 0 & 1 & $0.5 \mathrm{~V}_{\mathrm{dc}}$ & $\mathrm{C}$ & $\mathrm{C}$ \\
0 & 1 & 0 & 1 & 0 & 0 & 1 & 1 & 0 & 0 & $\mathrm{~V}_{\mathrm{dc}}$ & $\mathrm{C}$ & $\mathrm{C}$ \\
1 & 0 & 0 & 1 & 0 & 0 & 1 & 1 & 0 & 0 & $1.5 \mathrm{~V}_{\mathrm{dc}}$ & $\mathrm{C}$ & $\mathrm{C}$ \\
0 & 1 & 0 & 1 & 0 & 0 & 1 & 0 & 1 & 0 & $2 \mathrm{~V}_{\mathrm{dc}}$ & $\mathrm{C}$ & $\mathrm{C}$ \\
1 & 0 & 0 & 1 & 0 & 0 & 1 & 0 & 1 & 0 & $2.5 \mathrm{~V}_{\mathrm{dc}}$ & $\mathrm{C}$ & $\mathrm{C}$ \\
0 & 1 & 0 & 1 & 0 & 1 & 0 & 0 & 1 & 0 & $3 \mathrm{~V}_{\mathrm{dc}}$ & - & $\mathrm{D}$ \\
1 & 0 & 0 & 1 & 0 & 1 & 0 & 0 & 1 & 0 & $3.5 \mathrm{~V}_{\mathrm{dc}}$ & - & $\mathrm{D}$ \\
0 & 1 & 0 & 1 & 1 & 0 & 0 & 0 & 1 & 0 & $4 \mathrm{~V}_{\mathrm{dc}}$ & $\mathrm{D}$ & $\mathrm{D}$ \\
1 & 0 & 0 & 1 & 1 & 0 & 0 & 0 & 1 & 0 & $4.5 \mathrm{~V}_{\mathrm{dc}}$ & $\mathrm{D}$ & $\mathrm{D}$ \\
1 & 0 & 1 & 0 & 0 & 0 & 1 & 0 & 1 & 0 & $\mathrm{zero}$ & $\mathrm{C}$ & $\mathrm{C}$ \\
0 & 1 & 1 & 0 & 0 & 0 & 1 & 0 & 1 & 0 & -0.5 & $\mathrm{C}$ & $\mathrm{C}$ \\
1 & 0 & 1 & 0 & 0 & 0 & 1 & 1 & 0 & 0 & $-\mathrm{V}_{\mathrm{dc}}$ & $\mathrm{C}$ & $\mathrm{C}$ \\
0 & 1 & 1 & 0 & 0 & 0 & 1 & 1 & 0 & 0 & -1.5 & $\mathrm{C}$ & $\mathrm{C}$ \\
1 & 0 & 1 & 0 & 0 & 0 & 1 & 0 & 0 & 1 & $-2 \mathrm{~V}_{\mathrm{dc}}$ & $\mathrm{C}$ & $\mathrm{C}$ \\
0 & 1 & 1 & 0 & 0 & 0 & 1 & 0 & 0 & 1 & -2.5 & $\mathrm{C}$ & $\mathrm{C}$ \\
1 & 0 & 1 & 0 & 1 & 0 & 0 & 1 & 0 & 0 & $-3 \mathrm{~V}_{\mathrm{dc}}$ & $\mathrm{D}$ & - \\
0 & 1 & 1 & 0 & 1 & 0 & 0 & 1 & 0 & 0 & -3.5 & $\mathrm{D}$ & - \\
1 & 0 & 1 & 0 & 1 & 0 & 0 & 0 & 0 & 1 & $-4 \mathrm{~V}_{\mathrm{dc}}$ & $\mathrm{D}$ & $\mathrm{D}$ \\
0 & 1 & 1 & 0 & 1 & 0 & 0 & 0 & 0 & 1 & -4.5 & $\mathrm{D}$ & $\mathrm{D}$ \\
\hline
\end{tabular}




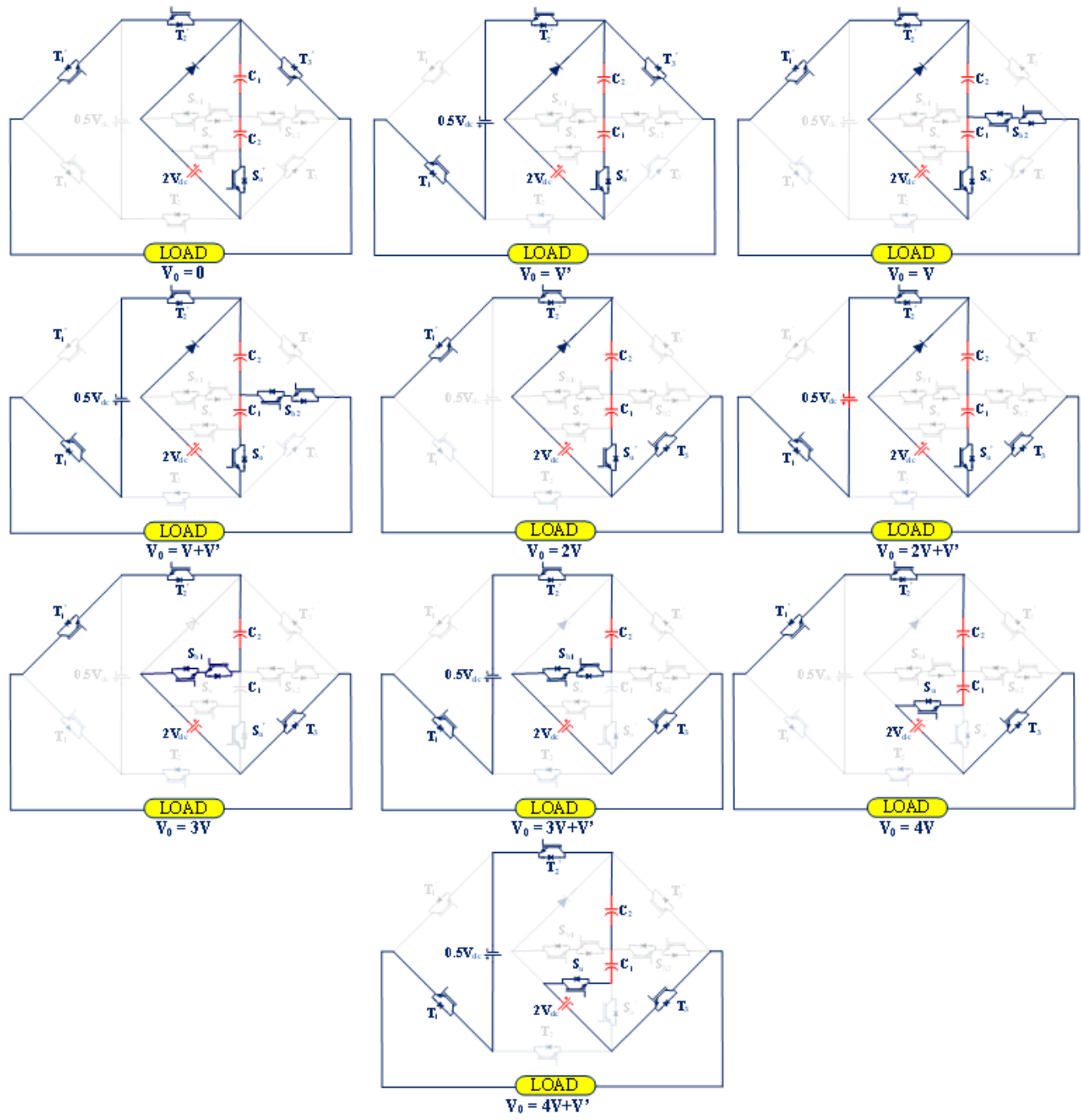

Figure 2. All positive conduction states.

The TSV (total standing voltage) is computed as the summation of these voltages. The bidirectional switches require two modules with the same rating.

$$
\mathrm{TSV}=\sum_{\mathrm{n}=1}^{10} \mathrm{Vsn}=30 \mathrm{~V}_{\mathrm{dc}}
$$

The per-unit TSV of the structure is given as:

$$
\mathrm{TSV}_{\text {p.u. }}=\frac{\mathrm{TSV}}{\mathrm{V}_{\text {o,peak }}}=\frac{30 \mathrm{~V}_{\mathrm{dc}}}{4.5 \mathrm{~V}_{\mathrm{dc}}}=6.66
$$

The modulation scheme is either low frequency-based (LS-PWM) or high-frequency carrier-based (CB-PWM). Modulation at low frequencies possesses the advantage of reduced switching losses, $\mathrm{dv} / \mathrm{dt}$ ratings and snubber losses. Low frequency-based modulation techniques comprise the nearest level control (NLC) and the selective harmonic elimination (SHE) methods. The SHE approach is optimum for reducing the filter size but involves the solution of complex non-linear transcendental equations, therefore, being computationally more intensive. Additionally, NLC is more convenient for closed-loop 
controlled systems. NLC-PWM has been used in this work. The visual representation of NLC-PWM is depicted in Figure 3. The modulation index $M_{a}$ is given as:

$$
\theta_{i}=M_{a} \sin ^{-1}\left(\frac{2 i-1}{N-1}\right)
$$

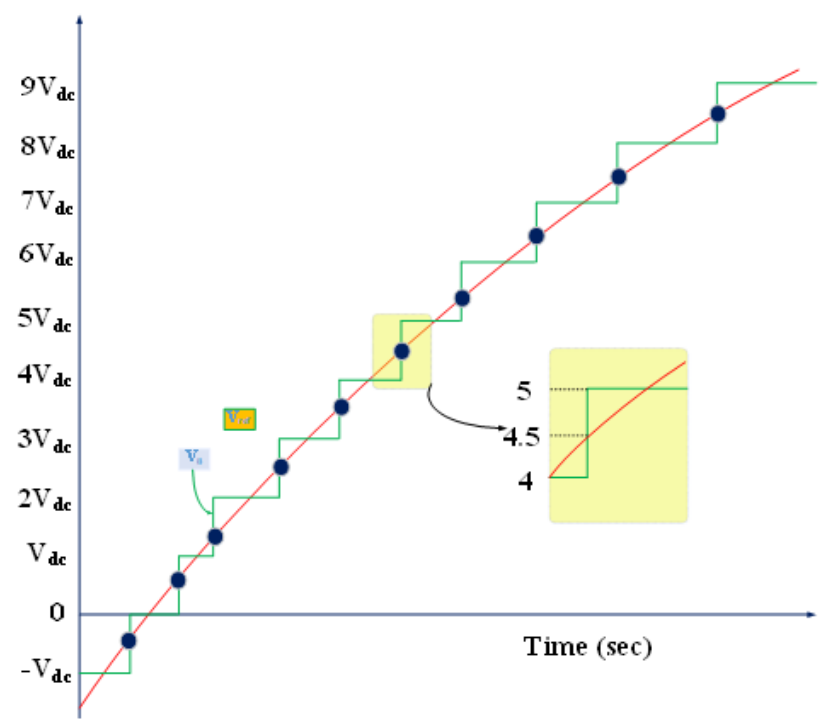

Figure 3. Nearest level modulation.

Knowing the modulation index $M_{a}$, number of levels $N$ and switch index $i$, the calculation for switching angle $\theta_{i}[36,37]$ is given as:

$$
M_{a}=\frac{V_{r e f}}{V_{0}}
$$

\section{Comparative Assessment}

The proposed SCMLI is compared with recently devised works with a similar level count. The basis for comparisons includes the quantity of power semiconductor switches, diodes, capacitors, gate drivers, boosting factor and cost function. The comparison is shown in Table 2. The proposed SCMLI is superior in terms of component count per unit level, particularly considering levels produced as compared to previous works. Additionally, the comparison is also made using the metric of the cost function (CF) as defined in [38]. An intelligent compact multilevel converter based on passivity ANFIS control was presented in [31].

$$
\begin{gathered}
C F=\left(N_{s w}+N_{g d}+N_{d}+N_{C}+\alpha \times T S V_{p u}\right) N_{d c} \\
N C F=\frac{C F}{N_{L}}
\end{gathered}
$$

Table 2. Comparative Assessment.

\begin{tabular}{cccccccccc}
\hline Topology & $\mathbf{N}_{\mathbf{L}}$ & $\mathbf{N}_{\mathbf{d c}}$ & $\mathbf{N}_{\mathbf{s w}}$ & $\mathbf{N}_{\mathbf{g d}}$ & $\mathbf{N}_{\mathbf{d}}$ & $\mathbf{N}_{\mathbf{c}}$ & TSV $_{\mathbf{p u}}$ & $\mathbf{V G}$ & $\mathbf{C F}$ \\
\hline$[24]$ & 11 & 2 & 11 & 11 & 0 & 1 & 4.4 & 1.67 & 4.66 \\
{$[26]$} & 13 & 2 & 14 & 11 & 0 & 2 & 5.33 & 2 & 4.56 \\
{$[27]$} & 17 & 2 & 10 & 10 & 2 & 2 & 5.5 & 2 & 3.14 \\
{$[28]$} & 17 & 2 & 10 & 10 & 2 & 2 & 5.5 & 2 & 3.14 \\
{$[29]$} & 13 & 2 & 11 & 10 & 1 & 1 & 6.3 & 1.5 & 4.18 \\
{$[30]$} & 13 & 2 & 18 & 15 & 0 & 2 & 5 & 2 & 5.76 \\
{$[31]$} & 17 & 2 & 18 & 14 & 2 & 4 & 6 & 2 & 4.82 \\
{$[32]$} & 19 & 2 & 12 & 12 & 6 & 4 & 5.8 & 2.25 & 3.85 \\
Proposed & 19 & 2 & 12 & 10 & 1 & 2 & 6.66 & 1.8 & 3.02 \\
\hline
\end{tabular}


From Table 2, it is seen that the proposed SCMLI has the lowest NCF for two values of $\alpha$. This verifies that the proposed converter has a high number of levels with lower component requirements and a cost-effective design.

\section{Power Loss Analysis}

The proposed converter's thermal loss model was developed to estimate the topology's loss distribution across various components and efficiencies. The non-ideality in semiconductor components leads to conduction $\left(P_{C}\right)$ and switching losses $\left(P_{S}\right)$. In other words, power dissipation across ON-state resistance leads to conduction losses, and noninstantaneous transitions between $\mathrm{ON}$ and $\mathrm{OFF}$ states lead to switching losses. The total conduction loss in IGBTs and diodes is obtained using:

$$
\begin{gathered}
P_{c_{s w}}=V_{s w} i(t)+R_{s} i^{\beta}(t) \\
P_{c_{D}}=V_{D} i(t)+R_{D} i^{2}(t) \\
P_{c}=\sum_{k=1}^{N_{s w}} \frac{1}{2 \pi} \int_{0}^{2 \pi}\left(V_{s w} i(t)+R_{s} i^{\beta}(t)\right) d t+\sum_{k=1}^{N_{D}} \frac{1}{2 \pi} \int_{0}^{2 \pi}\left(V_{D} i(t)+R_{D} i^{2}(t)\right) d t
\end{gathered}
$$

where $V_{s w}$ is the ON-state voltage drop across the switch and $V_{D}$ is the ON-state drop across the power diode. $R_{S}$ is the ON-state resistance of the switch, and $R_{D}$ stands for the ON-state resistance of the diode. Following an assumption of non-linear transitions between device current and voltages, the switching loss is for $N_{S}$ switches, and with $f$ switching frequency is evaluated as:

$$
P_{S}=\left[\sum_{k=1}^{N s}\left(N_{O N_{k}} E_{O N_{k}}+N_{O F F_{k}} E_{O F F_{k}}\right)\right] \times f,
$$

with $N_{O N_{k}}, N_{O F F_{k}}, E_{O N_{k}}$, and $E_{O F F_{k}}$ being associated with switch number $(k)$, are the number of transitions and energy losses in turning $\mathrm{ON}$ and $\mathrm{OFF}$, respectively. The total thermal is:

$$
P_{\text {loss }}=P_{c}+P_{s}
$$

Conversion efficiency is given by:

$$
\eta=\frac{P_{0}}{P_{0}+P_{\text {loss }}} \times 100 \%
$$

The PLECS platform was utilized for the thermal analysis of the SCMLI. The module IGW40N60H3, PG6DI capacitor is implemented with a peak voltage of $450 \mathrm{~V}$. Figure 4 shows the conversion efficiency as compared to two previous topologies. The corresponding distribution of losses for loads is shown in Figure 5. As evident, the conduction losses are dominant due to low-frequency NLC PWM. 


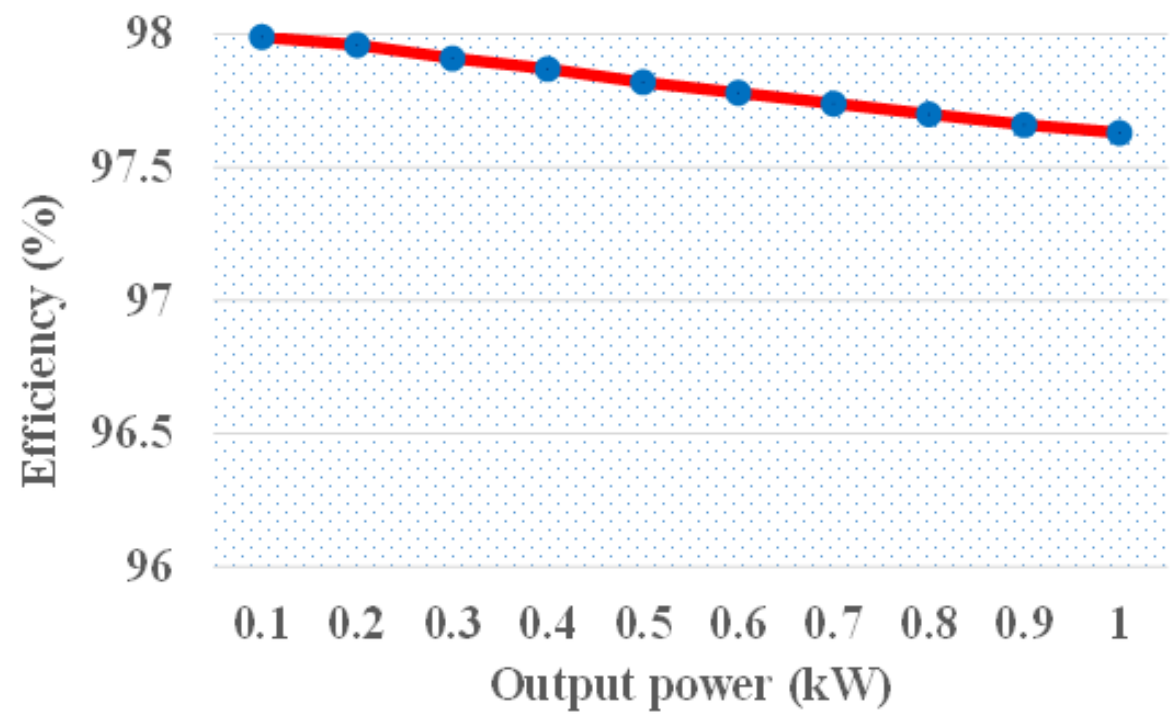

Figure 4. Efficiency curve.

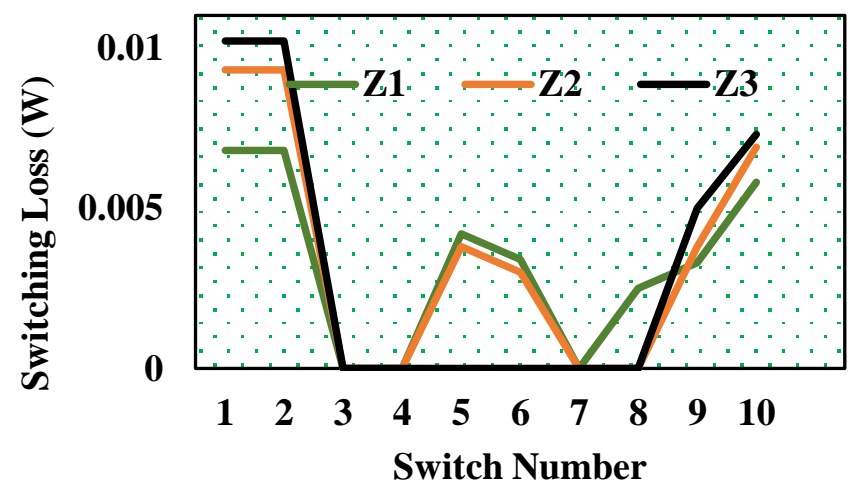

(a)

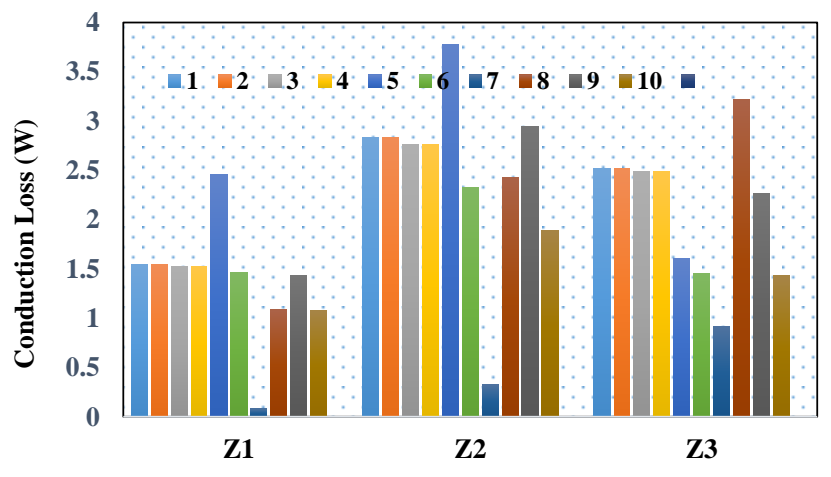

(b)

Figure 5. Loss distribution across switches (a) Switching Loss (b) Conduction Loss.

\section{Results and Discussion}

\subsection{Simulation Results}

The proposed SCMLI topology is simulated in MATLAB and PLECS environments. NLCPWM staircase modulation was used for generating a 19-level output with a $450 \mathrm{~V}$ peak at MI = 1.0 and $50 \mathrm{~Hz}$ frequency. The topology's dynamic performance with load change was verified, and the load voltage, current and capacitor voltage waveforms are illustrated in Figure 6a. The load was changed from $50 \Omega$ to $50 \Omega+40 \mathrm{mH}$ at t $=0.04 \mathrm{~s}$. Similarly, the output of the inverter with a varying modulation index of $\mathrm{MI}=0.8,0.9$ and 1 can be observed in Figure 6b. Notably, the balance in capacitor voltages is maintained irrespective of alteration in load or MI. Furthermore, the voltage and current stresses of the switches with a load of $50 \Omega+40 \mathrm{mH}$ are given in Figure $7 \mathrm{a}, \mathrm{b}$. 

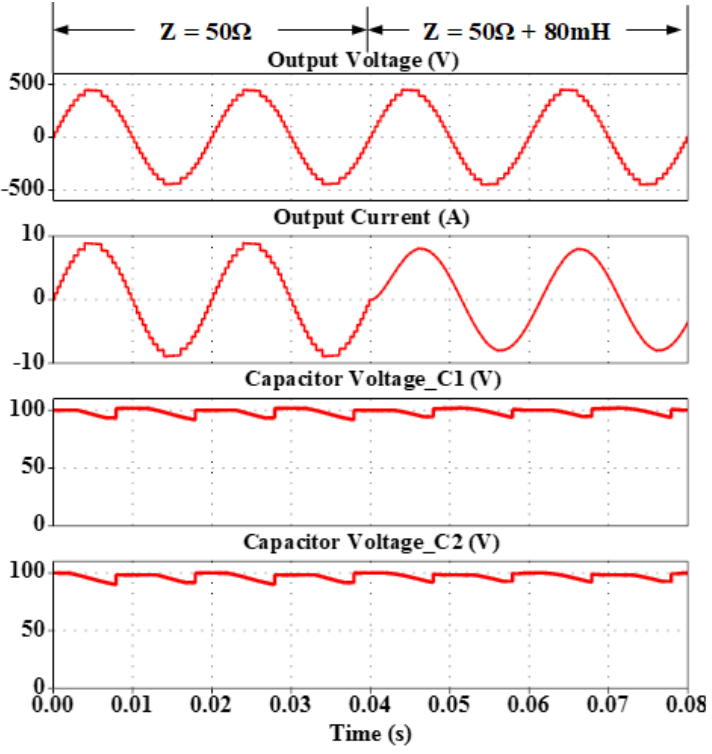

(a)
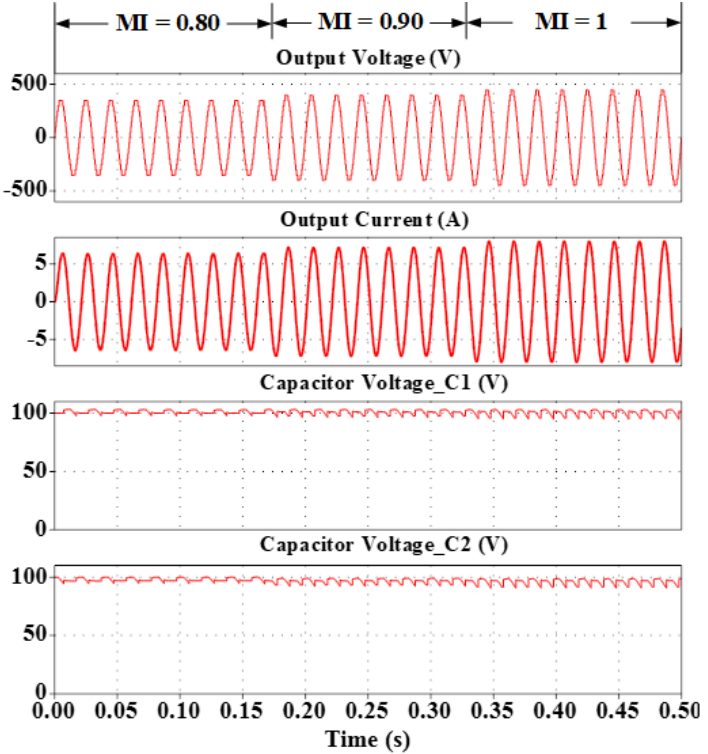

(b)

Figure 6. (a) Simulation results with load change (b) Simulation results with modulation index change.
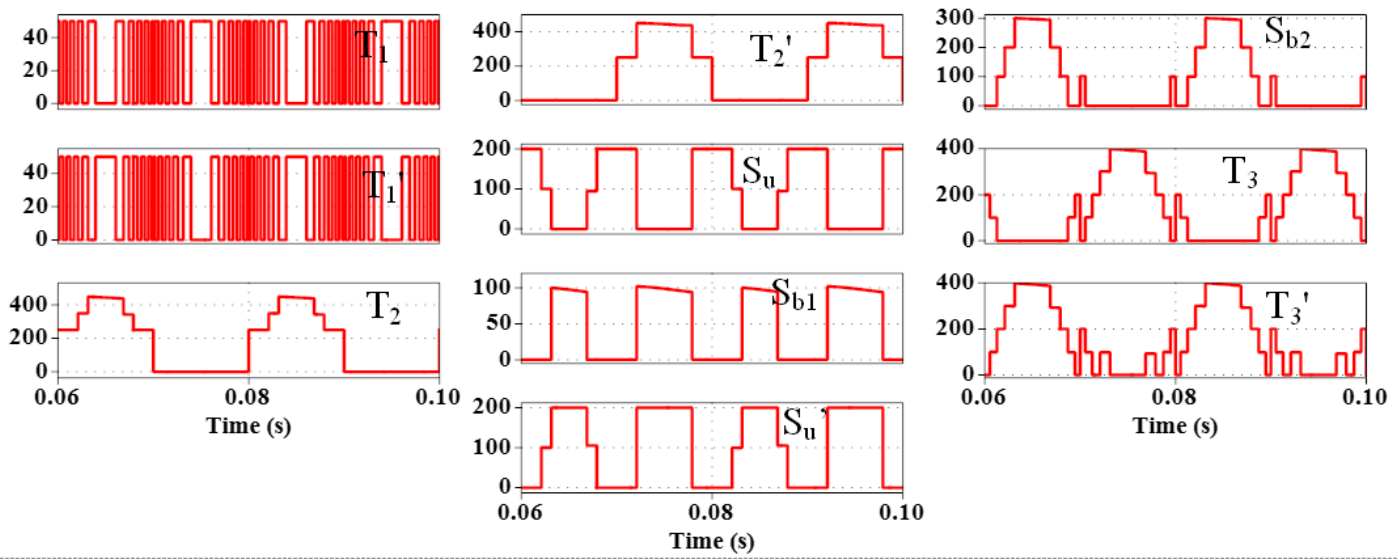

(a)

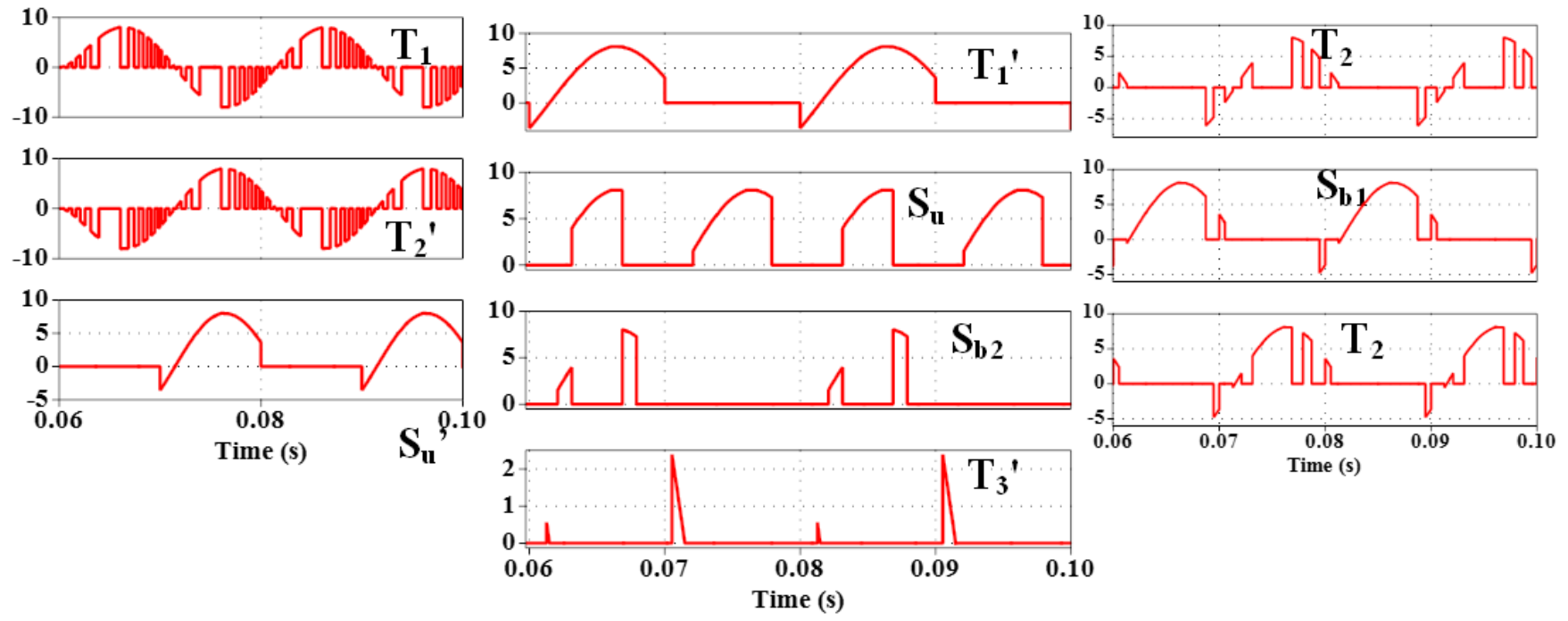

(b)

Figure 7. Switch stresses during simulation (a) Voltage Stress (b) Current Stress. 


\subsection{Experimental Verification}

The laboratory prototype of the SCMLI topology is shown in Figure 8. The IGBT (IGW40N60H3) and PG6DI capacitors were used. TMS320F28335 DSP and TLP250H gate drivers were used for gating pulse control. A Yokogawa DL1640 oscilloscope was used to capture the resulting waveforms. A peak voltage of $63 \mathrm{~V}$ at $\mathrm{MI}=1$ was created. Figure 9 depicts the 19-level load voltage waveform and current through a $210 \Omega$ load. The voltage and current waveforms are in phase with similar wave shapes. The peak voltage and current values are $63 \mathrm{~V}$ and 0.3 , respectively. Observably, the current lags the output voltage due to the inductive phase lag and is approaching a closer sinusoidal shape. To demonstrate the performance in dynamic conditions, R-load changes are also analyzed. The R-load changed from $210 \Omega$ to $105 \Omega$, as shown in Figure 10. Additionally, waveforms during no-load to R-load transition are given in Figure 11. The harmonic profile of the 19-level waveform can be seen in Figure 12. The waveform has a THD of 4.3\%, which meets EN50160 power quality standards and can eliminate filter demand due to minimal lower order harmonic content. The above results demonstrate the performance of the topology under varying operational requirements.

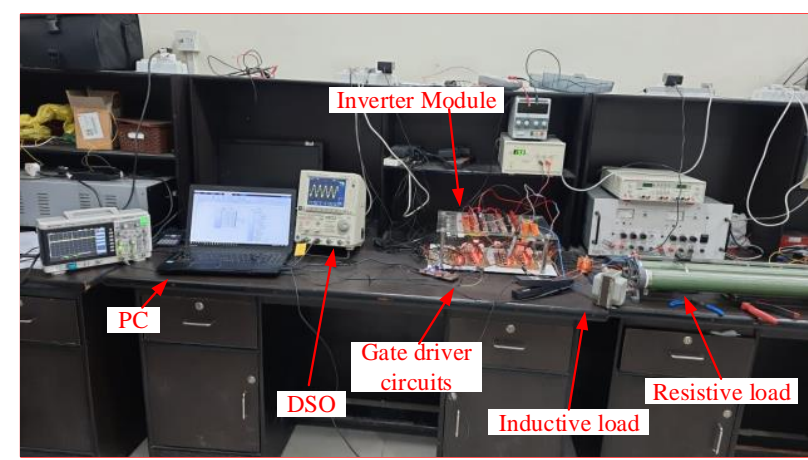

Figure 8. Experimental Prototype.

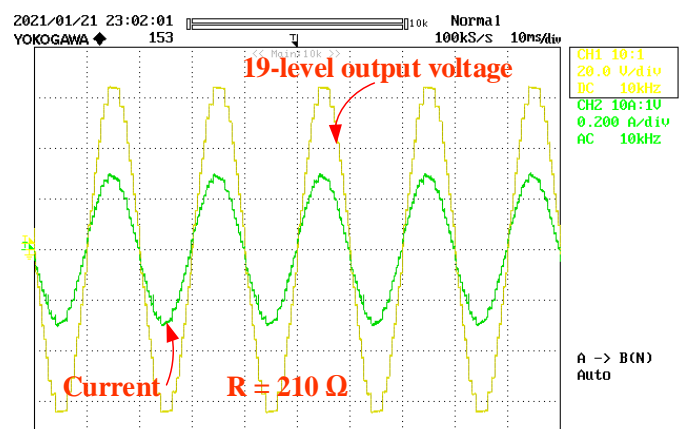

Figure 9. 19-level output waveform.

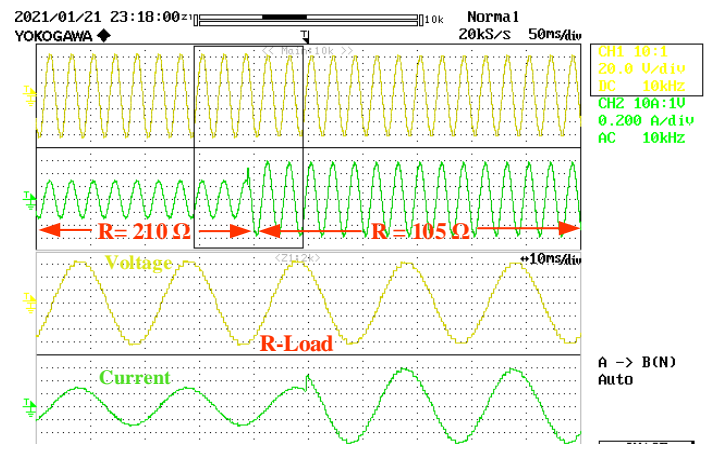

Figure 10. Load change from $210 \Omega$ to $105 \Omega$. 


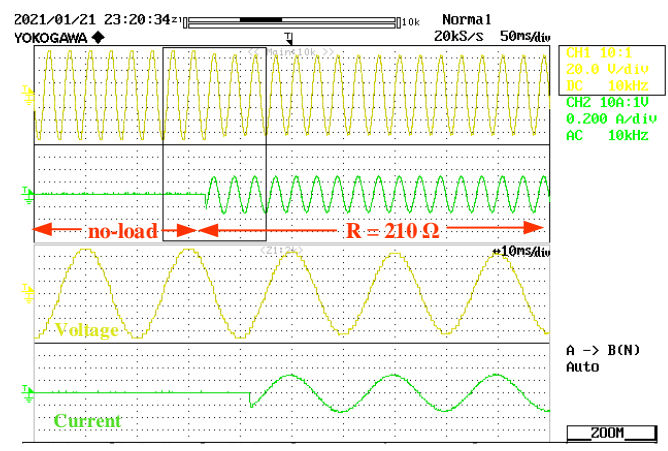

Figure 11. Load change from no-load to $210 \Omega$.
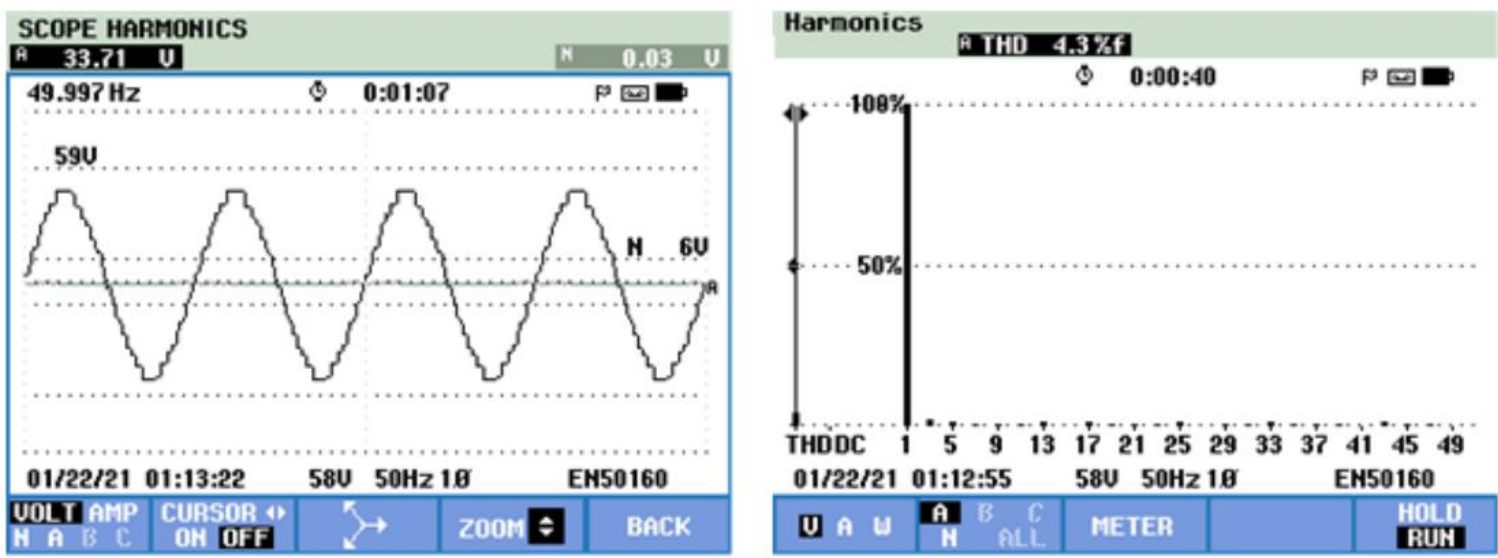

Figure 12. Harmonic spectrum.

\section{Conclusions}

A multisource step-up multilevel inverter with low component requirements and high power quality has been discussed. The operation of the proposed SCMLI is demonstrated, and the self-balancing property of capacitor voltages is shown. Analysis of previous works in developing various MLIs and switched-capacitor configurations with their advantages and setbacks is presented. A comparison of the proposed SCMLI with recent topologies was conducted. The topology's thermal loss analysis was carried out to show its thermal behavior and efficiency. Simulation results have been presented. Experimental results validate the performance in varied operating conditions (load and MI changes).

Author Contributions: Conceptualization, M.F. (Mohammad Fahad), M.T. and A.S.; formal analysis, M.F. (Mohammad Fahad), M.T., M.F. (Mohammad Faizan), A.A., A.S., H.D.T., S.A. and A.S.N.M.; funding acquisition, M.F. (Mohammad Fahad) and S.A.; investigation, M.F. (Mohammad Fahad), M.T., M.F. (Mohammad Faizan), A.A., A.S., H.D.T., S.A. and A.S.N.M.; methodology, M.F. (Mohammad Fahad), M.T., M.F. (Mohammad Faizan), A.A., A.S., H.D.T. and A.S.N.M.; supervision, M.T. and A.S.; writing—original draft, M.F. (Mohammad Fahad) and M.T.; writing—review and editing, M.F. (Mohammad Faizan), A.A., A.S., H.D.T., S.A. and A.S.N.M. All authors have read and agreed to the published version of the manuscript.

Funding: The authors extend their appreciation to King Saud University for funding this work through Researchers Supporting Project number (RSP-2021/387), King Saud University, Riyadh, Saudi Arabia.

Acknowledgments: The authors extend their appreciation to King Saud University for funding this work through Researchers Supporting Project number (RSP-2021/387), King Saud University, Riyadh, Saudi Arabia.

Conflicts of Interest: The authors declare no conflict of interest. 


\section{References}

1. Bhukya, M.N.; Kota, V.R.; Depuru, S.R. A Simple, Efficient, and Novel Standalone Photovoltaic Inverter Configuration with Reduced Harmonic Distortion. IEEE Access 2019, 7, 43831-43845. [CrossRef]

2. Dhanamjayulu, C.; Khasim, S.R.; Padmanaban, S.; Arunkumar, G.; Holm-Nielsen, J.B.; Blaabjerg, F. Design and Implementation of Multilevel Inverters for Fuel Cell Energy Conversion System. IEEE Access 2020, 8, 183690-183707. [CrossRef]

3. Chen, J.; Song, Q.; Yin, S.; Chen, J. On the Decentralized Energy Management Strategy for the All-Electric APU of Future More Electric Aircraft Composed of Multiple Fuel Cells and Supercapacitors. IEEE Trans. Ind. Electron. 2020, 67, 6183-6194. [CrossRef]

4. Celanovic, N.; Boroyevich, D. A comprehensive study of neutral-point voltage balancing problem in three-level neutral-pointclamped voltage source PWM inverters. IEEE Trans. Power Electron. 2000, 15, 242-249. [CrossRef]

5. Cao, W.; Mecrow, B.C.; Atkinson, G.J.; Bennett, J.W.; Atkinson, D.J. Overview of electric motor technologies used for more electric aircraft (MEA). IEEE Trans. Ind. Electron. 2012, 59, 3523-3531.

6. Pradeep Kumar, V.V.S.; Fernandes, B.G. A Fault-Tolerant Single-Phase Grid-Connected Inverter Topology with Enhanced Reliability for Solar PV Applications. IEEE J. Emerg. Sel. Top. Power Electron. 2017, 5, 1254-1262. [CrossRef]

7. Sarwar, M.I.; Sarwar, A.; Farooqui, S.A.; Tariq, M.; Fahad, M.; Beig, A.R.; Alamri, B. A Hybrid Nearest Level Combined with PWM Control Strategy: Analysis and Implementation on Cascaded H-Bridge Multilevel Inverter and its Fault Tolerant Topology. IEEE Access 2021, 9, 44266-44282. [CrossRef]

8. Rodríguez, J.; Bernet, S.; Wu, B.; Pontt, J.O.; Kouro, S. Multilevel voltage-source-converter topologies for industrial mediumvoltage drives. IEEE Trans. Ind. Electron. 2007, 54, 2930-2945. [CrossRef]

9. Omer, P.; Kumar, J.; Surjan, B.S. A Review on Reduced Switch Count Multilevel Inverter Topologies. IEEE Access 2020, 8, 22281-22302. [CrossRef]

10. Dewangan, N.K.; Gupta, S.; Gupta, K.K. Approach to synthesis of fault tolerant reduced device count multilevel inverters (FT RDC MLIs). IET Power Electron. 2019, 12, 476-482. [CrossRef]

11. Kumar, D.; Nema, R.K.; Gupta, S. Investigation of Fault-Tolerant Capabilities of Some Recent Multilevel Inverter Topologies. Int. J. Electron. 2020, 108, 1957-1976. [CrossRef]

12. Siddique, M.D.; Mekhilef, S.; Shah, N.M.; Memon, M.A. Optimal Design of a New Cascaded Multilevel Inverter Topology with Reduced Switch Count. IEEE Access 2019, 7, 24498-24510. [CrossRef]

13. Chappa, A.; Gupta, S.; Sahu, L.K.; Gautam, S.P.; Gupta, K.K. Symmetrical and Asymmetrical Reduced Device Multilevel Inverter Topology. IEEE J. Emerg. Sel. Top. Power Electron. 2019, 9, 885-896. [CrossRef]

14. Samizadeh, M.; Yang, X.; Karami, B.; Chen, W.; Blaabjerg, F.; Kamranian, M. A new topology of switched-capacitor multilevel inverter with eliminating leakage current. IEEE Access 2020, 8, 76951-76965. [CrossRef]

15. Khan, M.N.H.; Forouzesh, M.; Siwakoti, Y.P.; Li, L.; Blaabjerg, F. Switched Capacitor Integrated (2n + 1)-Level Step-Up SinglePhase Inverter. IEEE Trans. Power Electron. 2020, 35, 8248-8260. [CrossRef]

16. Taheri, A.; Rasulkhani, A.; Ren, H.P. An Asymmetric Switched Capacitor Multilevel Inverter with Component Reduction. IEEE Access 2019, 7, 127166-127176. [CrossRef]

17. Jagabar Sathik, M.; Sandeep, N.; Almakhles, D.; Blaabjerg, F. Cross Connected Compact Switched-Capacitor Multilevel Inverter (C3-SCMLI) Topology with Reduced Switch Count. IEEE Trans. Circuits Syst. II Express Briefs 2020, 67, 3287-3291. [CrossRef]

18. Ahmad, J.; Pervez, I.; Sarwar, A.; Tariq, M.; Fahad, M.; Chakrabortty, R.K.; Ryan, M.J. Performance Analysis and Hardware-In-theLoop (HIL) Validation of Single Switch High Voltage Gain DC-DC Converters for MPP Tracking in Solar PV System. IEEE Access 2020, 9, 48811-48830. [CrossRef]

19. Khoun Jahan, H.; Abapour, M.; Zare, K. Switched-Capacitor-Based Single-Source Cascaded H-Bridge Multilevel Inverter Featuring Boosting Ability. IEEE Trans. Power Electron. 2019, 34, 1113-1124. [CrossRef]

20. Siddique, M.D.; Mekhilef, S.; Shah, N.M.; Sandeep, N.; Ali, J.S.M.; Iqbal, A.; Ahmed, M.; Ghoneim, S.S.M.; Al-Harthi, M.M.; Alamri, B.; et al. A Single DC Source Nine-Level Switched-Capacitor Boost Inverter Topology with Reduced Switch Count. IEEE Access 2020, 8, 5840-5851. [CrossRef]

21. Lee, S.S. A Single-Phase Single-Source 7-Level Inverter with Triple Voltage Boosting Gain. IEEE Access 2018, 6, $30005-30011$. [CrossRef]

22. Bikdeli, E.; Adabi, J.; Rezanejad, M.; Gholamian, S.A. Investigation on Fault Tolerant Capability of a Single Source Switched Capacitor Multilevel Inverter. IEEE Trans. Ind. Electron. 2020, 68, 7921-7930. [CrossRef]

23. Mehrasa, M.; Babaie, M.; Sharifzadeh, M.; Al-Haddad, K. An Input-Output Feedback Linearization Control Method Synthesized by Artificial Neural Network for Grid-Tied Packed E-Cell Inverter. IEEE Trans. Ind. Appl. 2021, 57, 3131-3142. [CrossRef]

24. Taghvaie, A.; Adabi, J.; Rezanejad, M. A Multilevel Inverter Structure Based on a Combination of Switched-Capacitors and DC Sources. IEEE Trans. Ind. Inform. 2017, 13, 2162-2171. [CrossRef]

25. Babaie, M.; Mehrasa, M.; Sharifzadeh, M.; Al-Haddad, K. Floating Weighting Factors ANN-MPC Based on Lyapunov Stability for Seven-Level Modified PUC Active Rectifier. IEEE Trans. Ind. Electron. 2022, 69, 387-398. [CrossRef]

26. Rawa, M.; Siddique, M.D.; Mekhilef, S.; Shah, N.M.; Bassi, H.; Seyedmahmoudian, M.; Horan, B.; Stojcevski, A. Dual input switched-capacitor-based single-phase hybrid boost multilevel inverter topology with reduced number of components. IET Power Electron. 2020, 13, 881-891. [CrossRef]

27. Samadaei, E.; Kaviani, M.; Bertilsson, K. A 13-levels module (K-Type) with two DC sources for multilevel inverters. IEEE Trans. Ind. Electron. 2019, 66, 5186-5196. [CrossRef] 
28. Siddique, M.D.; Mekhilef, S.; Sarwar, A.; Alam, A.; Mohamed Shah, N. Dual asymmetrical dc voltage source based switched capacitor boost multilevel inverter topology. IET Power Electron. 2020, 13, 1481-1486. [CrossRef]

29. Alishah, R.S.; Hosseini, S.H.; Babaei, E.; Sabahi, M.; Zare, A. Extended high step-up structure for multilevel converter. IET Power Electron. 2016, 9, 1894-1902. [CrossRef]

30. Zamiri, E.; Vosoughi, N.; Hosseini, S.H.; Barzegarkhoo, R.; Sabahi, M. A New Cascaded Switched-Capacitor Multilevel Inverter Based on Improved Series-Parallel Conversion with Less Number of Components. IEEE Trans. Ind. Electron. 2016, 63, 3582-3594. [CrossRef]

31. Lee, S.S.; Lee, K.B.; Alsofyani, I.M.; Bak, Y.; Wong, J.F. Improved Switched-Capacitor Integrated Multilevel Inverter with a DC Source String. IEEE Trans. Ind. Appl. 2019, 55, 7368-7376. [CrossRef]

32. Barzegarkhoo, R.; Moradzadeh, M.; Zamiri, E.; Madadi Kojabadi, H.; Blaabjerg, F. A New Boost Switched-Capacitor Multilevel Converter with Reduced Circuit Devices. IEEE Trans. Power Electron. 2018, 33, 6738-6754. [CrossRef]

33. Barzegarkhoo, R.; Zamiri, E.; Moradzadeh, M.; Shadabi, H. Symmetric hybridised design for a novel step-up 19-level inverter. IET Power Electron. 2017, 10, 1377-1391. [CrossRef]

34. Roy, T.; Sadhu, P.K. A Step-Up Multilevel Inverter Topology Using Novel Switched Capacitor Converters with Reduced Components. IEEE Trans. Ind. Electron. 2021, 68, 236-247. [CrossRef]

35. Talooki, M.F.; Rezanejad, M.; Khosravi, R.; Samadaei, E. A Novel High Step-Up Switched-Capacitor Multilevel Inverter with Self-Voltage Balancing. IEEE Trans. Power Electron. 2021, 36, 4352-4359. [CrossRef]

36. Nguyen, M.H.; Kwak, S. Nearest-Level Control Method with Improved Output Quality for Modular Multilevel Converters. IEEE Access 2020, 8, 110237-110250. [CrossRef]

37. Hu, P.; Jiang, D. A level-increased nearest level modulation method for modular multilevel converters. IEEE Trans. Power Electron. 2015, 30, 1836-1842. [CrossRef]

38. Deliri, S.; Varesi, K.; Siwakoti, Y.P.; Blaabjerg, F. A boost type switched-capacitor multi-level inverter for renewable energy sources with Self-Voltage balancing of capacitors. Int. J. Energy Res. 2021, 45, 15217-15230. [CrossRef]

39. Mehrasa, M.; Babaie, M.; Zafari, A.; Al-Haddad, K. Passivity ANFIS-Based Control for an Intelligent Compact Multilevel Converter. IEEE Trans. Ind. Inform. 2021, 17, 5141-5151. [CrossRef]

40. Karimi, M.; Kargar, P.; Varesi, K.; Sanjeevikumar, P. Power quality improvement by a double-source multilevel inverter with reduced device and standing voltage on switches. In Power Quality in Modern Power Systems; Academic Press: Cambridge, MA, USA, 2021; pp. 245-282.

41. Deliri, S.; Varesi, K.; Siwakoti, Y.P.; Blaabjerg, F. Generalized diamond-type single DC-source switched-capacitor based multilevel inverter with step-up and natural voltage balancing capabilities. IET Power Electron. 2021, 14, 1208-1218. [CrossRef] 